\title{
Meyer dysplasia: a diagnosis to consider
}

\author{
Ana Teresa Maria, ${ }^{1}$ Raquel Firme, ${ }^{1}$ Pedro Magro, ${ }^{2}$ Sílvia Jorge ${ }^{1}$
}

${ }^{1}$ Department of Paediatrics, Hospital de Cascais, Cascais, Portugal

${ }^{2}$ Department of Orthopaedics, Hospital de Cascais, Cascais, Portugal

\section{Correspondence to}

Dr Ana Teresa Maria, anateresamaria@gmail.com

Accepted 25 February 2016

\section{DESCRIPTION}

A 2-year-old boy with unremarkable medical history presented to the emergency room due to sudden onset of left hip pain and limping gait, without fever or trauma. On observation, he had no signs of inflammation and no limitation of joint mobilisation. Hip radiography revealed widening of the medial joint space and a smaller, irregular, ossification nucleus of the proximal left femur, with no condensation and no other epiphysial changes (figure 1). Laboratory data showed no elevated inflammatory parameters. The patient was submitted to hip ultrasonography, which excluded effusion; and CT scan, which confirmed the X-ray findings. The diagnosis of Meyer dysplasia (MD) was then suggested and symptoms resolved within a few days with minimal analgaesia. At the age of 4 , he remains asymptomatic with progressive radiological improvement at orthopaedic follow-up.

MD is a rare hip developmental disorder, characterised by delay and irregularity of ossification of the proximal epiphysial nucleus of the femur. ${ }^{12}$

The differential diagnosis consists mainly of Perthes disease (PD). Recent series suggest that up to $5 \%$ of patients initially diagnosed with PD have

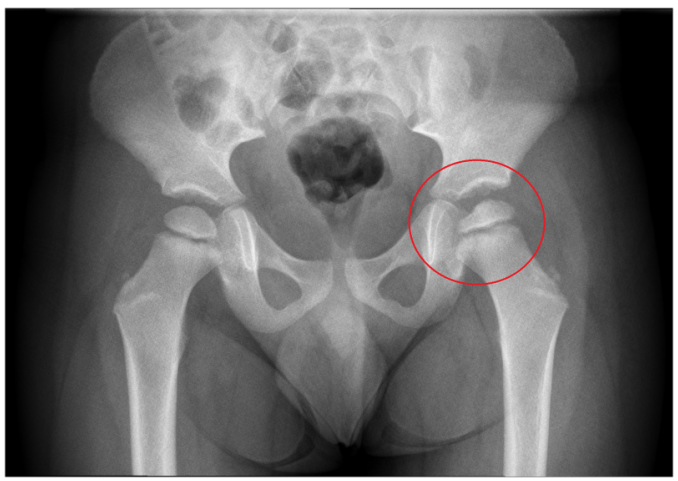

To cite: Maria AT, Firme $\mathrm{R}$ Magro $\mathrm{P}$, et al. BMJ Case Rep Published online: [please include Day Month Year] doi:10.1136/bcr-2015214282
CrossMark

Figure 1 Radiological appearance in Meyer dysplasia, with irregularity of the proximal epiphysial nucleus of the femur and absence of consolidation, fragmentation and epiphysial collapse.
MD. ${ }^{1}$ In $\mathrm{MD}$, there are multiple independent ossification foci, which gradually coalesce to form a single nucleus. Unlike PD, there are no aspects of epiphysial condensation, fragmentation, subchondral fractures or collapse. Symptoms, when present, are mild and transient. ${ }^{3}$ The diagnosis can be achieved by plain radiography, not requiring additional investigations. Evolution is favourable, with the epiphysis reaching normal shape and size. ${ }^{2} 3$ Treatment is not necessary and prognosis is good. ${ }^{13}$ Clinical and radiographic surveillance is recommended to document resolution. ${ }^{13}$

\section{Learning points}

- Meyer dysplasia (MD) is a rare but benign condition. It should not be confused with Perthes disease (PD), which involves severe changes in hip development.

- A wider knowledge of clinicoradiological features of MD is important for its prompt recognition and to prevent children from undergoing unnecessary diagnostic and therapeutic procedures. In this case, ultrasonography and CT could have been avoided.

Competing interests None declared.

Patient consent Obtained.

Provenance and peer review Not commissioned; externally peer reviewed.

\section{REFERENCES}

1 Muzaffar N, Song HR, Devmurari K, et al. Meyer's dysplasia: delayed ossification of the femoral head as a differential diagnosis in Perthes' disease. Acta Orthop Belg 2010;76:608-12.

2 Meyer J. Dysplasia epiphysealis capitis femoris. A clinical-radiological syndrome and its relationship to Legg-Calvé-Perthes disease. Acta Orthop Scand 1964;34:183-97.

3 Harel L, Kornreich L, Ashkenazi S, et al. Meyer dysplasia in the differential diagnosis of hip disease in young children. Arch Pediatr Adolesc Med 1999:153:942-5.

Copyright 2016 BMJ Publishing Group. All rights reserved. For permission to reuse any of this content visit

http://group.bmj.com/group/rights-licensing/permissions.

BMJ Case Report Fellows may re-use this article for personal use and teaching without any further permission.

Become a Fellow of BMJ Case Reports today and you can:

- Submit as many cases as you like

- Enjoy fast sympathetic peer review and rapid publication of accepted articles

- Access all the published articles

- Re-use any of the published material for personal use and teaching without further permission

For information on Institutional Fellowships contact consortiasales@bmjgroup.com

Visit casereports.bmj.com for more articles like this and to become a Fellow 